\title{
320-row CT scanning: reduction in tube current parallels reduction in radiation exposure?
}

\author{
E. E. van der Wall • J. E. van Velzen • \\ F. R. de Graaf $\cdot$ J. W. Jukema • J. D. Schuijf •
}

J. J. Bax

Received: 23 November 2010/Accepted: 26 November 2010/Published online: 7 December 2010

(C) The Author(s) 2010. This article is published with open access at Springerlink.com

Nowadays, multiple studies involving over several thousands of patients have established that CT angiography is a highly accurate noninvasive approach for delineation of the presence and severity of coronary atherosclerosis [1-35]. With its high negative predictive value cardiac CT is optimally suited for the evaluation of patients with a low or intermediate risk of coronary disease, allowing the non-invasive exclusion of coronary disease at relatively low cost and risk [36-48]. However, the appropriate radiation dose remains an important issue in cardiac CT. On one hand, a too low radiation dose may result in a high level of image noise and therefore in non-evaluable images. On the other hand, using higher radiation exposure levels may put patients at unnecessary risk of radiation damage [49-58]. Effective strategies to reduce radiation dose, such as prospective gating, ECG-correlated modulation of the tube current, and tube voltage below $100 \mathrm{kV}$, are becoming more and more available [59-65]. Leschka et al. [61] showed that adjustment of the scan length of CT coronary angiography using

Editorial comment on to the article of Zhang et al. (doi: 10.1007/s10554-010-9754-5).

E. E. van der Wall $(\bowtie)$. J. E. van Velzen

F. R. de Graaf · J. W. Jukema · J. D. Schuijf · J. J. Bax Department of Cardiology, Leiden University Medical Center, P.O. Box 9600, Leiden, The Netherlands

e-mail: e.e.van_der_wall@lumc.nl the images from calcium scoring instead of the scout was associated with a $16 \%$ reduction in radiation dose of dual-source CT coronary angiography. In a large multicenter study of coronary CT angiography in patients with excellent heart rate control, Labounty et al. [62] reported that the use of minimal padding (i.e. additional surrounding X-ray beam on time), was associated with a substantial reduction in radiation dose (from mean $5.7 \mathrm{mSv}$ to mean $2.0 \mathrm{mSv}$ ) together with preserved image interpretability. Rogalla et al. [63] showed that the anterior-posterior diameter adapted tube current in dynamic volume CT coronary angiography provided a new simple and practical approach to keep image quality constant by accounting for differences in patient size. Maintaining a constant image quality in CT, independent of patient body habitus, significantly contributed to a substantially improved diagnostic image quality together with a reduced radiation dose for the patient. Blankstein et al. [64] investigated the effective radiation dose and image quality of $100 \mathrm{kV}$ versus $120 \mathrm{kV}$ tube voltage among patients referred for cardiac dual source CT imaging in 294 consecutive patients. They convincingly demonstrated that use of low $\mathrm{kV}$ resulted in a substantial reduction of radiation dose without compromising image quality. The effective radiation dose for the 100 and $120 \mathrm{kV}$ scans was 8.5 and $15.4 \mathrm{mSv}$, respectively. In the recently published PROTECTION II trial, Hausleiter et al. [65] studied 400 non-obese patients undergoing CT angiography with either 100 or $120 \mathrm{kV}$ CT 
angiography. The study specifically examined the impact of a reduction in tube voltage to $100 \mathrm{kV}$ using 64-slice CT angiography systems from three different manufacturers. It was demonstrated that a further $31 \%$ reduction in radiation exposure could be obtained with $100 \mathrm{kV}$ tube voltage settings while image quality was preserved.

In the current issue of the International Journal of Cardiovascular Imaging, Zhang et al. [66] prospectively evaluated image quality parameters, contrast volume and radiation dose at the $100 \mathrm{kV}$ tube voltage setting during CT coronary angiography. Interestingly, the authors used a 320-row CT scanner. The authors studied 107 consecutive patients with a heart rate $<65$ beats per minute who underwent prospective ECG-triggered CT coronary angiography. A total of 40 patients with a body mass index $<25 \mathrm{~kg} / \mathrm{m}^{2}$ were scanned using $100 \mathrm{kV}$ tube voltage settings, whereas 67 patients were scanned using the $120 \mathrm{kV}$ protocol. Contrast-to-noise ratios and contrast material volumes were calculated. Adequate diagnostic image quality was achieved in $98.2 \%$ of coronary segments with $100 \mathrm{kV}$ CT coronary angiography, and in $98.6 \%$ of coronary segments with $120 \mathrm{kV}$ CT coronary angiography, without significant differences in image quality scores for each coronary segment. Vessel attenuation, image noise, and contrast-to-noise ratios were not significantly different between the $100 \mathrm{kV}$ and $120 \mathrm{kV}$ protocols. Mean contrast injection rate and mean material volume were significantly lower for the $100 \mathrm{kV}$ tube voltage setting than for the $120 \mathrm{kV}$ protocol. The effective radiation dose was $2.12 \pm 0.19 \mathrm{mSv}$ for $100 \mathrm{kV} \mathrm{CT}$ coronary angiography, which is a reduction of 54\% compared to $4.61 \pm 0.82 \mathrm{mSv}$ for $120 \mathrm{kV}$ CT coronary angiography. A $100 \mathrm{kV}$ CT coronary angiography can be implemented in patients with a body mass index $<25 \mathrm{~kg} / \mathrm{m}^{2}$. The $100 \mathrm{kV}$ setting allowed significant reductions in contrast material volume and effective radiation dose while maintaining adequate diagnostic image quality.

The interesting study by Zhang et al. [66] represents the first evaluation by a 320-row CT scanner of the $100 \mathrm{kV}$ protocol for CT coronary angiography with respect to image quality, contrast volume, and radiation exposure. This is an appropriate and timely approach, as the use of 320-row MSTC scanners is increasing over the past years [67-71]. In principle, whole-heart 320-row CT angiography avoids exposure-intensive overscanning and overranging, offering the potential to significantly reduce radiation dose. The main results of the present study indicate that $100 \mathrm{kV}$ CT coronary angiography using a 320row scanner is feasible in patients with a body mass index of $<25 \mathrm{~kg} / \mathrm{m}$, visualizing more than $98 \%$ of coronary segments with appropriate diagnostic image quality. A dose reduction of even $54 \%$ for the $100 \mathrm{kV}$ tube setting was reached. The image quality was reduced by motion artifacts in nearly $21 \%$ of segments. However, this held for both the $100 \mathrm{kV}$ and the $120 \mathrm{kV}$ tube voltage settings. Blurring by calcification was more common for the $100 \mathrm{kV}$ protocol than for the $120 \mathrm{kV}$ protocol. Theoretically, the $100 \mathrm{kV}$ voltage setting may increase blooming artifacts from dense structures such as calcification, which precludes accurate evaluation of the lumen of the coronary arteries. Consequently, future studies using the $100 \mathrm{kV}$ protocol should focus on the influence of calcification on image quality, and the potential interference of the $100 \mathrm{kV}$ protocol with edequate evaluation of both coronary arteries and coronary stenoses, especially for calcified segments and identification of soft plaques.

To conclude, Zhang et al. [66] have clearly demonstrated that for patients with a body mass index of $<25 \mathrm{~kg} / \mathrm{m}^{2}, 100 \mathrm{kV}$ CT coronary angiography can be validly performed using a 320-row CT scanner. This approach allows a significant reduction of $54 \%$ in contrast and radiation doses, while maintaining adequate diagnostic image quality. The study extends previous findings that the reduction in tube current may be a feasible standard addition to the other strategies for reducing potential radiation exposure in patients undergoing CT coronary angiography.

Open Access This article is distributed under the terms of the Creative Commons Attribution Noncommercial License which permits any noncommercial use, distribution, and reproduction in any medium, provided the original author(s) and source are credited.

\section{References}

1. Schuijf JD, Pundziute G, Jukema JW et al (2006) Diagnostic accuracy of 64-slice multislice computed tomography in the noninvasive evaluation of significant coronary artery disease. Am J Cardiol 98:145-148

2. Dirksen MS, Bax JJ, de Roos A et al (2002) Usefulness of dynamic multislice computed tomography of left 
ventricular function in unstable angina pectoris and comparison with echocardiography. Am J Cardiol 90: $1157-1160$

3. Roeters van Lennep JE, Westerveld HT, Erkelens DW, van der Wall EE (2002) Risk factors for coronary heart disease: implications of gender. Cardiovasc Res 53:538-549

4. van de Veire NR, Schuijf JD, De Sutter J et al (2006) Noninvasive visualization of the cardiac venous system in coronary artery disease patients using 64-slice computed tomography. J Am Coll Cardiol 48:1832-1838

5. van der Wall EE, Heidendal GA, den Hollander W, Westera G, Roos JP (1980) I-123 labeled hexadecenoic acid in comparison with thallium-201 for myocardial imaging in coronary heart disease. A preliminary study. Eur J Nucl Med 5:401-405

6. Bavelaar-Croon CD, Pauwels EK, van der Wall EE (2001) Gated single-photon emission computed tomographic myocardial imaging: a new tool in clinical cardiology. Am Heart J 141:383-390

7. Molhoek SG, Bax JJ, Bleeker GB et al (2004) Comparison of response to cardiac resynchronization therapy in patients with sinus rhythm versus chronic atrial fibrillation. Am J Cardiol 94:1506-1509

8. Groothuis JG, Beek AM, Meijerink MR, Brinckman SL, Hofman MB, van Rossum AC (2010) Towards a noninvasive anatomical and functional diagnostic work-up of patients with suspected coronary artery disease. Neth Heart J 18:270-273

9. van Mieghem CA, de Feyter PJ (2009) Combining noninvasive anatomical imaging with invasive functional information: an unconventional but appropriate hybrid approach. Neth Heart J 17:292-294

10. Knaapen P, de Haan S, Hoekstra OS et al (2010) Cardiac PET-CT: advanced hybrid imaging for the detection of coronary artery disease. Neth Heart J 18:90-98

11. van der Wall EE, van Dijkman PR, de Roos A et al (1990) Diagnostic significance of gadolinium-DTPA (diethylenetriamine penta-acetic acid) enhanced magnetic resonance imaging in thrombolytic treatment for acute myocardial infarction: its potential in assessing reperfusion. Br Heart $\mathrm{J}$ 63:12-17

12. Wijpkema JS, Dorgelo J, Willems TP et al (2007) Discordance between anatomical and functional coronary stenosis severity. Neth Heart J 15:5-11

13. van de Wal RM, van Werkum JW, le Cocq d'Armandville MC et al (2007) Giant aneurysm of an aortocoronary venous bypass graft compressing the right ventricle. Neth Heart J 15:252-254

14. de Leeuw JG, Wardeh A, Sramek A, van der Wall EE (2007) Pseudo-aortic dissection after primary PCI. Neth Heart J 15:265-266

15. Braun S, van der Wall EE, Emanuelsson S, Kobrin I (1996) Effects of a new calciumantagonist, mibefradil (Ro 40-5967), on silent ischemia in patients with stable chronic angina pectoris: a multicenter placebo-controlled study. The mibefradil international study group. J Am Coll Cardiol 27:317-322

16. ten Kate GJ, Wuestink AC, de Feyter PJ (2008) Coronary artery anomalies detected by MSCT-angiography in the adult. Neth Heart J 16:369-375
17. Schuijf JD, Jukema JW, van der Wall EE, Bax JJ (2007) Multi-slice computed tomography in the evaluation of patients with acute chest pain. Acute Card Care 9:214-221

18. Groen JM, Greuter MJ, Vliegenthart R et al (2008) Calcium scoring using 64-slice MDCT, dual source CT and EBT: a comparative phantom study. Int J Cardiovasc Imaging 24:547-556

19. van Werkhoven JM, Schuijf JD, Jukema JW et al (2008) Anatomic correlates of a normal perfusion scan using 64slice computed tomographic coronary angiography. Am J Cardiol 101:40-45

20. Bakx AL, van der Wall EE, Braun S, Emanuelsson H, Bruschke AV, Kobrin I (1995) Effects of the new calcium antagonist mibefradil (Ro 40-5967) on exercise duration in patients with chronic stable angina pectoris: a multicenter, placebocontrolled study. Ro 40-5967 International Study Group. Am Heart J 130:748-757

21. Schuijf JD, Bax JJ, van der Wall EE (2007) Anatomical and functional imaging techniques: basically similar or fundamentally different? Neth Heart J 15:43-44

22. Juwana YB, Wirianta J, Suryapranata H, de Boer MJ (2007) Left main coronary artery stenosis undetected by 64-slice computed tomography: a word of caution. Neth Heart J 15:255-256

23. van Dijkman PR, van der Wall EE, de Roos A et al (1991) Acute, subacute, and chronic myocardial infarction: quantitative analysis of gadolinium-enhanced MR images. Radiology 180:147-151

24. Pundziute G, Schuijf JD, Jukema JW et al (2007) Prognostic value of multislice computed tomography coronary angiography in patients with known or suspected coronary artery disease. J Am Coll Cardiol 49:62-70

25. Henneman MM, Schuijf JD, Pundziute G et al (2008) Noninvasive evaluation with multislice computed tomography in suspected acute coronary syndrome: plaque morphology on multislice computed tomography versus coronary calcium score. J Am Coll Cardiol 52:216-222

26. de Nooijer R, Verkleij CJ, von der Thüsen JH et al (2006) Lesional overexpression of matrix metalloproteinase-9 promotes intraplaque hemorrhage in advanced lesions but not at earlier stages of atherogenesis. Arterioscler Thromb Vasc Biol 26:340-346

27. Hoogendoorn LI, Pattynama PM, Buis B, van der Geest RJ, van der Wall EE, de Roos A (1995) Noninvasive evaluation of aortocoronary bypass grafts with magnetic resonance flow mapping. Am J Cardiol 75:845-848

28. van der Laarse A, Kerkhof PL, Vermeer F et al (1988) Relation between infarct size and left ventricular performance assessed in patients with first acute myocardial infarction randomized to intracoronary thrombolytic therapy or to conventional treatment. Am J Cardiol 61:1-7

29. van der Wall EE, den Hollander W, Heidendal GA, Westera G, Majid PA, Roos JP (1981) Dynamic myocardial scintigraphy with 123I-labeled free fatty acids in patients with myocardial infarction. Eur $\mathrm{J}$ Nucl Med 6:383-389

30. Vliegen HW, Doornbos J, de Roos A, Jukema JW, Bekedam MA, van der Wall EE (1997) Value of fast gradient echo magnetic resonance angiography as an adjunct to coronary arteriography in detecting and 
confirming the course of clinically significant coronary artery anomalies. Am J Cardiol 79:773-776

31. Matheijssen NA, Louwerenburg HW, van Rugge FP et al (1996) Comparison of ultrafast dipyridamole magnetic resonance imaging with dipyridamole SestaMIBI SPECT for detection of perfusion abnormalities in patients with one-vessel coronary artery disease: assessment by quantitative model fitting. Magn Reson Med 35:221-228

32. Ertas G, van Beusekom HM, van der Giessen WJ (2009) Late stent thrombosis, endothelialisation and drug-eluting stents. Neth Heart J 17:177-180

33. Pluim BM, Lamb HJ, Kayser HW et al (1998) Functional and metabolic evaluation of the athlete's heart by magnetic resonance imaging and dobutamine stress magnetic resonance spectroscopy. Circulation 97:666-672

34. Scholte AJ, Schuijf JD, Kharagjitsingh AV et al (2008) Different manifestations of coronary artery disease by stress SPECT myocardial perfusion imaging, coronary calcium scoring, and multislice CT coronary angiography in asymptomatic patients with type 2 diabetes mellitus. J Nucl Cardiol 15:503-509

35. Scholte AJ, Schuijf JD, Kharagjitsingh AV et al (2008) Prevalence of coronary artery disease and plaque morphology assessed by multi-slice computed tomography coronary angiography and calcium scoring in asymptomatic patients with type 2 diabetes. Heart 94:290-295

36. Torn M, Bollen WL, van der Meer FJ, van der Wall EE, Rosendaal FR (2005) Risks of oral anticoagulant therapy with increasing age. Arch Intern Med 165:1527-1532

37. Ypenburg C, Schalij MJ, Bleeker GB et al (2007) Impact of viability and scar tissue on response to cardiac resynchronization therapy in ischaemic heart failure patients. Eur Heart J 28:33-41

38. Ypenburg C, Roes SD, Bleeker GB et al (2007) Effect of total scar burden on contrast-enhanced magnetic resonance imaging on response to cardiac resynchronization therapy. Am J Cardiol 99:657-660

39. de Roos A, Matheijssen NA, Doornbos J et al (1990) Myocardial infarct size after reperfusion therapy: assessment with Gd-DTPA-enhanced MR imaging. Radiology 176:517-521

40. de Roos A, Matheijssen NA, Doornbos J, van Dijkman PR, van Rugge PR, van der Wall EE (1991) Myocardial infarct sizing and assessment of reperfusion by magnetic resonance imaging: a review. Int J Card Imaging 7:133-138

41. van Rugge FP, van der Wall EE, van Dijkman PR, Louwerenburg HW, de Roos A, Bruschke AV (1992) Usefulness of ultrafast magnetic resonance imaging in healed myocardial infarction. Am J Cardiol 70:1233-1237

42. Holman ER, van Jonbergen HP, van Dijkman PR, van der Laarse A, de Roos A, van der Wall EE (1993) Comparison of magnetic resonance imaging studies with enzymatic indexes of myocardial necrosis for quantification of myocardial infarct size. Am J Cardiol 71:1036-1040

43. Schuijf JD, Bax JJ, van der Wall EE (2005) Non-invasive visualization of the coronary arteries with multi-detector row computed tomography; influence of technical advances on clinical applicability. Int $\mathbf{J}$ Cardiovasc Imaging 21:343-345

44. Bleeker GB, Schalij MJ, Boersma E et al (2007) Relative merits of M-mode echocardiography and tissue Doppler imaging for prediction of response to cardiac resynchronization therapy in patients with heart failure secondary to ischemic or idiopathic dilated cardiomyopathy. Am J Cardiol 99:68-74

45. Ypenburg C, Sieders A, Bleeker GB et al (2007) Myocardial contractile reserve predicts improvement in left ventricular function after cardiac resynchronization therapy. Am Heart J 154:1160-1165

46. Ypenburg C, van der Wall EE, Schalij MJ, Bax JJ (2008) Imaging in cardiac resynchronisation therapy. Neth Heart $\mathbf{J}$ 16:S36-S40

47. Nemes A, Geleijnse ML, van Geuns RJ et al (2008) Dobutamine stress MRI versus threedimensional contrast echocardiography: it's all black and white. Neth Heart J $16: 217-218$

48. van der Geest RJ, Niezen RA, van der Wall EE, de Roos A, Reiber JH (1998) Automated measurement of volume flow in the ascending aorta using MR velocity maps: evaluation of inter- and intraobserver variability in healthy volunteers. J Comput Assist Tomogr 22:904-911

49. Tops LF, Schalij MJ, Holman ER, van Erven L, van der Wall EE, Bax JJ (2006) Right ventricular pacing can induce ventricular dyssynchrony in patients with atrial fibrillation after atrioventricular node ablation. J Am Coll Cardiol 48:1642-1648

50. Bleeker GB, Holman ER, Steendijk P et al (2006) Cardiac resynchronization therapy in patients with a narrow QRS complex. J Am Coll Cardiol 48:2243-2250

51. Bleeker GB, Bax JJ, Fung JW et al (2006) Clinical versus echocardiographic parameters to assess response to cardiac resynchronization therapy. Am J Cardiol 97:260-263

52. van Rugge FP, Boreel JJ, van der Wall EE et al (1991) Cardiac first-pass and myocardial perfusion in normal subjects assessed by sub-second Gd-DTPA enhanced MR imaging. J Comput Assist Tomogr 15:959-965

53. van der Wall EE, Wall HW, de Roos A, Bruschke AV (1995) Magnetic resonance imaging in coronary artery disease. Circulation 92:2723-2739

54. Oemrawsingh PV, Mintz GS, Schalij MJ, Zwinderman AH, Jukema JW, van der Wall EE (2003) Intravascular ultrasound guidance improves angiographic and clinical outcome of stent implantation for long coronary artery stenoses: final results of a randomized comparison with angiographic guidance (TULIP Study). Circulation 107:62-67

55. Portegies MC, Schmitt R, Kraaij CJ et al (1991) Lack of negative inotropic effects of the new calcium antagonist Ro 40-5967 in patients with stable angina pectoris. J Cardiovasc Pharmacol 18:746-751

56. Tops LF, Bax JJ, Zeppenfeld K et al (2005) Fusion of multislice computed tomography imaging with threedimensional electroanatomic mapping to guide radiofrequency catheter ablation procedures. Heart Rhythm 2: 1076-1081

57. Gerber TC, Kuzo RS, Morin R (2005) Techniques and parameters for estimating radiation exposure and dose in cardiac computed tomography. Int $\mathbf{J}$ Cardiovasc Imaging 21:165-176

58. Hausleiter J, Meyer T, Hermann F et al (2009) Estimated radiation dose associated with cardiac CT angiography. JAMA 301:500-507 
59. Zhang LJ, Yang GF, Huang W, Zhou CS, Chen P, Lu GM (2010) Incidence of anomalous origin of coronary artery in 1879 Chinese adults on dual-source CT angiography. Neth Heart J 18:466-470

60. van der Wall EE (2009) CT angiography, underuse, overuse, or appropriate use? Neth Heart J 17:223

61. Leschka S, Kim CH, Baumueller S et al (2010) Scan length adjustment of CT coronary angiography using the calcium scoring scan: effect on radiation dose. AJR Am J Roentgenol 194:W272-W277

62. Labounty TM, Leipsic J, Min JK et al (2010) Effect of padding duration on radiation dose and image interpretation in prospectively ECG-triggered coronary CT angiography. AJR Am J Roentgenol 194:933-937

63. Rogalla P, Blobel J, Kandel S et al (2010) Radiation dose optimisation in dynamic volume CT of the heart: tube current adaptation based on anterior-posterior chest diameter. Int J Cardiovasc Imaging. [Epub ahead of print]

64. Blankstein R, Bolen MA, Pale R et al (2010) Use of $100 \mathrm{kV}$ versus $120 \mathrm{kV}$ in Cardiac Dual source computed tomography: effect on radiation dose and image quality. Int $\mathrm{J}$ Cardiovasc Imaging. [Epub ahead of print]

65. Hausleiter J, Martinoff S, Hadamitzky M et al (2010) Image Quality and Radiation Exposure With a Low Tube Voltage Protocol for Coronary CT Angiography Results of the PROTECTION II Trial. JACC Cardiovasc Imaging 3:1113-1123
66. Zhang C, Zhang Z, Yan Z, Xu L, Yu W, Wang R. 320-row CT coronary angiography: effect of $100-\mathrm{kV}$ tube voltages on image quality, contrast volume, and radiation dose. Int $\mathbf{J}$ Cardiovasc Imaging. [Epub ahead of print]

67. Dewey M, Zimmermann E, Deissenrieder F et al (2009) Noninvasive coronary angiography by 320-row computed tomography with lower radiation exposure and maintained diagnostic accuracy: comparison of results with cardiac catheterization in a head-to-head pilot investiga- tion. Circulation 120:867-875

68. de Graaf FR, Schuijf JD, van Velzen JE et al (2010) Diagnostic accuracy of 320-row multidetector computed tomography coronary angiography to noninvasively assess in-stent restenosis. Invest Radiol 45:331-340

69. de Graaf FR, Schuijf JD, van Velzen JE et al (2010) Assessment of global left ventricular function and volumes with 320-row multidetector computed tomography: a comparison with 2D-echocardiography. J Nucl Cardiol 17:225-331

70. de Graaf FR, Schuijf JD, van Velzen JE et al (2010) Diagnostic accuracy of 320-row multidetector computed tomography coronary angiography in the non-invasive evaluation of significant coronary artery disease. Eur Heart J 31:1908-1915

71. Tatsugami F, Matsuki M, Inada Y et al (2010) Feasibility of low-volume injections of contrast material with a body weight-adapted iodine-dose protocol in 320-detector row coronary CT angiography. Acad Radiol 17:207-211 